\title{
PLANT BREEDING REVIEWS
}

Volume 1 
Plant Breeding Reviews is sponsored by the American Society for Horticultural Science, the Crop Science Society of America, the Society of American Foresters, the National Council of Commercial Plant Breeders, and the AVI Publishing Company

\section{Editorial Board, Volume 1}

Dermot P. Coyne

John M. Poehlman 


\title{
PLANT BREEDING REVIEWS
}

Volume 1

\author{
edited by \\ Jules Janick \\ Purdue University
}

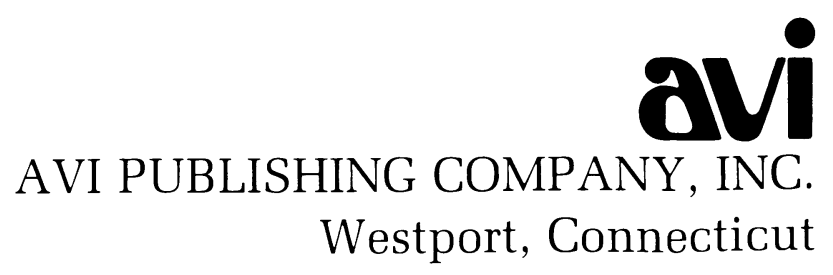


(C) Copyright 1983 by

THE AVI PUBLISHING COMPANY, INC.

Westport, Connecticut

Softcover reprint of the hardcover 1st edition 1983

All rights reserved. No part of this work covered by the copyright hereon may be reproduced or used in any form or by any means-graphic, electronic, or mechanical, including photocopying, recording, taping, or information storage and retrieval systems - without written permission of the publisher. 


\section{Contents}

Contributors ix

Preface $x i$

1 Dedication:

Henry A. Jones (1889-1981)

Plant Breeder Extraordinaire

Thomas W. Whitaker

Text

Publications of H.A. Jones

1

7

2 The Genetics of Petunia 11

André Cornu and Daniel Maizonnier

II. Chromosomes 13

III. Chromosome Numbers 16

IV. Genes 21

V. Chromosome Mapping 31

VI. Mutagenesis and Mutability 34

VII. Somatic Cell Investigations 44

$\begin{array}{ll}\text { VIII. Conclusion } & 48\end{array}$

3 Breeding Common Bean for Improved Quantity and Quality of Seed Protein 59

F. A. Bliss and John W. S. Brown

I. Introduction 60

II. Composition of Seed Protein 61

III. Variation in Seed Protein Expression 70

IV. Utilization of Genetic Variation for Improvement
Through Breeding

V. Use of Molecular Genetic Engineering $\quad 89$

VI. The Impact of Improved Seed Protein Quantity and Quality 91 
4 Genetics of Storage Protein in Maize 103

C. Y. Tsai

I. Introduction 103

II. Definition 104

III. Chemistry 105

IV. Genetic Regulation 110

V. Relationship with Grain Quality and Productivity 120

VI. Concluding Remarks 128

5 The Use of Endosperm Genes for Sweet Corn Improvement

C. D. Boyer and J. C. Shannon

I. Introduction 139

II. Historical Perspective 140

III. Variability of Endosperm Genes $\quad 142$

IV. Biochemical Considerations 144

V. Current Cultivars in Production 149

VI. Problems and Perspectives 151

6 Breeding Pearl Millet 162

Glenn W. Burton

$\begin{array}{rlr}\text { I. } & \text { Introduction } & 163 \\ \text { II. } & \text { Reproduction } & 165 \\ \text { III. } & \text { Cytogenetics } & 167 \\ \text { IV. } & \text { Germplasm } & 167 \\ \text { V. } & \text { Breeding } & 170\end{array}$

7 Breeding Soybeans Resistant to Diseases 183

J. R. Wilcox

I. Introduction 184

II. Breeding Methods $\quad 185$

III. Fungal Diseases 188

IV. Bacterial Diseases 209

V. Virus Diseases 212

VI. Nematodes 217

VII. Summary and Conclusions 221

8 The Genetic Improvement of Black Walnut for Timber Production 236

Walter F. Beineke

I. Introduction and Historical Perspective 237

II. Floral Structure and Reproduction 238

III. Germplasm Sources and Preservation 244

IV. Variation and Inheritance 247

V. Breeding Strategies 251

VI. Seed Orchards 257

VII. Production and Distribution of Improved Stock 260

VIII. Future Directions 261 
9 The Genes of Lettuce and Closely Related Species

R. W. Robinson, J. D. McCreight, and E. J. Ryder

I. Gene Nomenclature

II. Gene Descriptions

III. Gene Linkage

10 Breeding Apple Rootstocks

James N. Cummins and Herb S. Aldwinckle

I. Introduction

296

II. Breeding Programs 299

III. A Sequential Approach to Apple Rootstock Breeding 321

IV. Screening Protocols 324

V. Breeding for Specific Orchard Attributes 329

VI. Nursery Characteristics 339

VII. Tolerance of Factors of Physical Environment 346

VIII. Resistances to Diseases and Animal Pests 358

IX. Seed Propagated Rootstocks 373

X. Novel Methods of Improving Genotypes 374

XI. Conclusion 376

$\begin{array}{ll}\text { Index } & 395\end{array}$ 


\section{Contributors}

ALDWINCKLE, HERB S., New York State Agricultural Experiment Station, College of Agriculture and Life Sciences, Cornell University, Geneva, New York 14456

BEINEKE, WALTER F., Department of Forestry and Natural Resources, Purdue University, West Lafayette, Indiana 47907

BLISS, F.A., Department of Horticulture, University of Wisconsin, Madison, Wisconsin 53706

BOYER, C.D., Department of Horticulture, Rutgers University, New Brunswick, New Jersey 08903

BROWN, JOHN W.S., Agrigenetics Corporation, Agrigenetics Research Park, Madison, Wisconsin 53716

BURTON, GLENN W., United States Department of Agriculture, Agricultural Research Service, and the University of Georgia, College of Agriculture, Coastal Plain Station, Tifton, Georgia 31793

CORNU, ANDRÉ, Station d'Amélioration des Plantes, Institut National de la Recherche Agronomique, Dijon, France

CUMMINS, JAMES N., New York State Agricultural Experiment Station, College of Agriculture and Life Sciences, Cornell University, Geneva, New York 14456

MAIZONNIER, DANIEL, Station d'Amélioration des Plantes, Institut National de la Recherche Agronomique, Dijon, France

MCCREIGHT, J.D., United States Department of Agriculture, Agricultural Research Service, Salinas, California 93915

ROBINSON, R.W., New York State Agricultural Experiment Station, Cornell University, Geneva, New York 14456

RYDER, E.J., United States Department of Agriculture, Agricultural Research Service, Salinas, California 93915

SHANNON, J.C., Department of Horticulture, The Pennsylvania State University, University Park, Pennsylvania 16802 
TSAI, C.Y., Department of Botany and Plant Pathology, Purdue University, West Lafayette, Indiana 47907

WHITAKER, THOMAS W., Department of Biology, University of California, San Diego, La Jolla, California 92093

WILCOX, J.R., United States Department of Agriculture, Agricultural Research Service, and Purdue University, West Lafayette, Indiana 47907 


\section{Preface}

Plant breeding, the domestication and systematic improvement of crop species, is the basis of past and present agriculture. Our socalled primitive progenitors selected practically all our present-day crop plants, and the improvement wrought through millenia of selection has so changed some of them that in many cases their links to the past have been obliterated. There is no doubt that this ranks among the greatest of human achievements. Although plant breeding has been a continuous empirical activity for as long as humans have forsaken the vagaries and thrill of hunting for the security and toil of agriculture, genetic crop improvement is now very much of a twentieth-century discipline. Its scientific underpinnings date to the beginning of this century with the discovery of Gregor Mendel's classic 1865 paper on the inheritance of seven characters in the garden pea. If any science can be traced to single event, the best example is surely found in the conception of modern genetics that appears in this single creative work.

The relationship of plant breeding progress to advances in genetics has become closely entwined. Mendel himself was concerned with crop improvement and worked on schemes for apple and pear breeding. Plant breeding also has claims on other scientific and agricultural disciplines_botany, plant pathology, biochemistry, statistics, taxonomy, entomology, and cytology, to name a few-and has also impinged on our social, ethical, economic, and political consciousness. Recently world food supplies have been in precarious balance with population growth in many areas of the world. The acceleration in the spread of modern agricultural technology in the 1960s (known as the Green Revolution) was based on advances in plant breeding, specificially the introduction of short-stemmed, fertilizer-responsive wheat and rice that staved off food shortages and famines; at least for the short term. With the increasing cost of energy inputs for crop production, breeding efforts are required to develop more biologically efficient crops adapted to biotic and abiotic stresses. Recent advances in molecular biology, under the sobriquet of genetic engineering, have been touted as our saviors for the 
long term. Time will tell. Clearly plant breeding and modern biology have merged destinies.

Notwithstanding its pivotal position in agricultural progress, plant breeding has been slighted in the scientific communication system. Few journals are devoted exclusively to plant breeding (none in the United States!), and although there are two international review journals devoted to general genetics, topics in plant breeding have been few and diminishing. It may be that traditional plant breeding information has tended to become craft- and commodity-oriented, which has eroded the concept of plant breeding as a unique discipline.

The resultant fragmentation of the plant breeding literature suggests that a review journal devoted to this subject is particularly appropriate. Thus, the goal of Plant Breeding Reviews will be to consolidate all aspects related to crop improvement. It will endeavor to emphasize the major agronomic, horticultural, and forest crops whether for food, fiber, ornamental, or medicinal use; but species of minor economic importance will not be slighted. It will consider crop plants in the broadest sense, including fungi and bacteria. Topics dealing with the theory of breeding systems and methodologies, testing, and evaluation, as well as matters pertaining to the profession of plant breeding including plant breeders' rights, will be included. We shall not neglect plant breeders themselves and in each volume will recognize the career and achievements of at least one of our own. I am pleased to dedicate Volume 1 to the late Dr. H. A. Jones.

It is a pleasure to acknowledge Drs. Dermot P. Coyne and John M. Poehlman, members of the Editorial Board for Volume 1, and to recognize W. W. Tressler of AVI Publishing Company for his assistance in bringing the concept of Plant Breeding Reviews from an idea to an actuality. 


\section{PLANT BREEDING REVIEWS}

Volume 1 


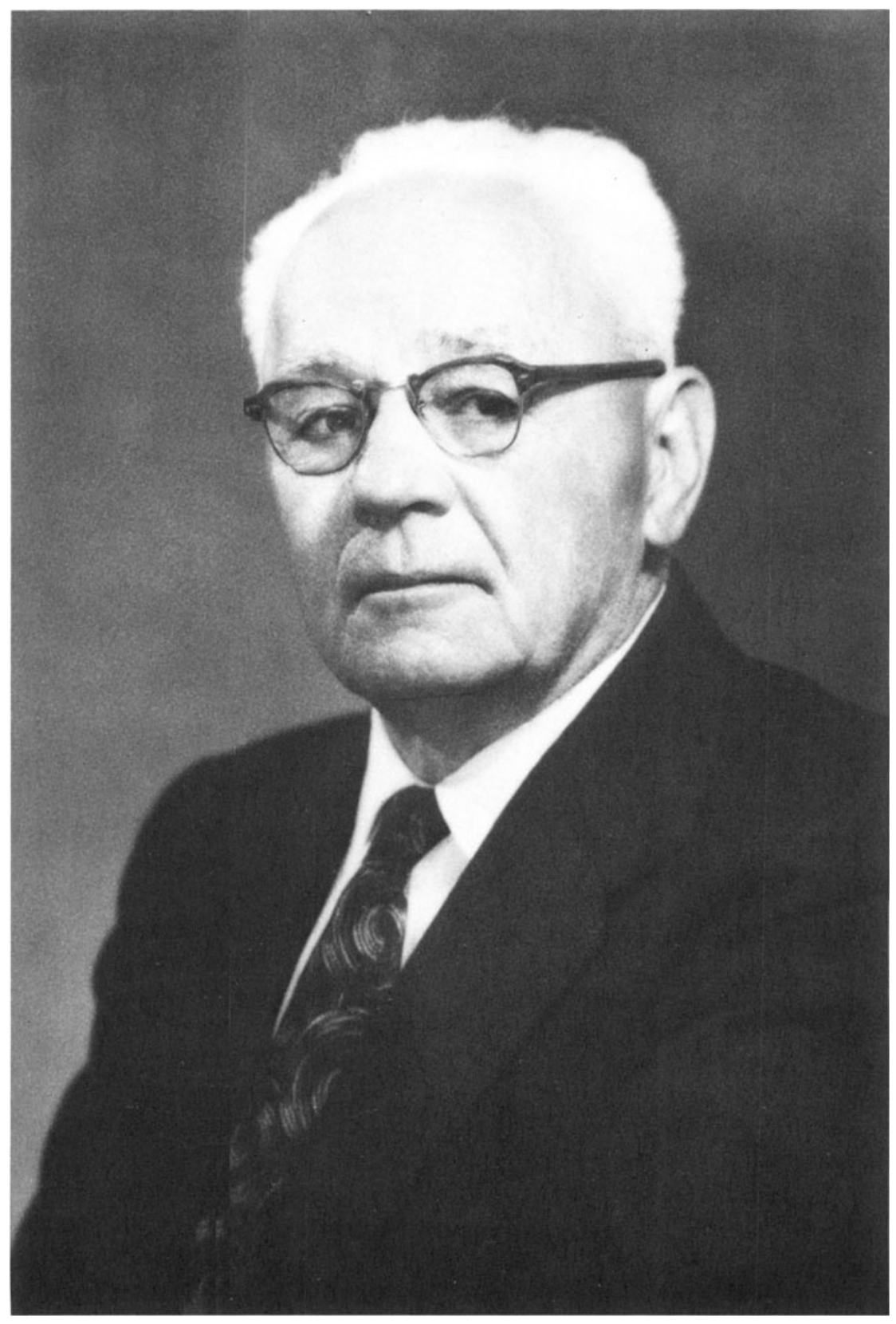

Henry A. Jones 